Original Paper http://ajol.info/index.php/ijbcs http://indexmedicus.afro.who.int

\title{
Defatted Detarium senegalense seed-based diet alters lipid profile, antioxidants level and sperm morphology in male albino rats
}

\author{
Sarah Onyenibe NWOZO ${ }^{1 *}$, Tolulope Latorera ADEBOWALE ${ }^{1}$ and \\ Babatunji Emmanuel OYINLOYE ${ }^{2}$ \\ ${ }^{I}$ Nutritional and Industrial Biochemistry Unit, Biochemistry Department, College of Medicine, University of \\ Ibadan, Ibadan, Nigeria. \\ ${ }^{2}$ Department of Biochemistry, College of Science, Afe Babalola University, Ado Ekiti, Nigeria. \\ *Corresponding author; E-mail: sonwozo@yahoo.com; onyenibe.nwozo@mail.ui.edu.ng; \\ Tel: +234 (0)802-365-8268; Fax: 234-2-810-3043
}

\begin{abstract}
Due to high cost of protein relative to other major nutrients, as part of search for cheaper alternative source for good quality protein for dietary purposes, we evaluated Detarium senegalense seed meal by comparing growth performance, tissue and reproductive toxicity markers in rats with those on soybean. Defatted Detarium senegalense (DDS) ground seed powder was used for feed formulation for test animals while the control group had soybean as protein source for eight weeks. Maximum percentage protein was 19\% for all compounded feeds, soybean diet feed rats served as control (T1), T2 had 19\% DDS only, while T3 - T6 had $16 \%, 12 \%, 8 \%$ and $4.8 \%$ DDS and protein content was made up to $19 \%$ using soybeans. Body weights, lipid profile, markers of liver toxicity, lipid peroxidation, sperm morphology and characteristics as well as tissue histology (liver, kidney and testes) were examined using standard methods. Whole seed residue, DDS seed flour and control diets (soybeans) were analyzed for proximate content. DDS seed residue-based diet (T2) caused decrease in both body and organ weights compared to control rats (T1). DDS residue-based feed caused increase in liver protein concentration while kidney protein content decreased except in groups T5 and T6 on $8 \%$ and $4.8 \%$ DDS residue. There was no significant variations $(\mathrm{P}>0.05)$ in sperm viability but there was a significant $(\mathrm{P}<0.05)$ decrease in sperm count in group $\mathrm{T} 2$ compared to control $(\mathrm{T} 1)$. Statistically significant morphological changes were observed in head less tail, bent tail, curved tail and bent mid-piece. DDS elicited increase in serum total cholesterol, HDL-c and LDL-c in all test groups compared to control but caused decrease in triglyceride in T2. Serum urea level, AST and ALT were higher in T2 relative to control rats. Histopathological examination showed evidence of liver tissue damage but none in the kidney and testes.
\end{abstract}

(c) 2016 International Formulae Group. All rights reserved.

Keywords: DDS seed residue feed, growth, antioxidants, lipid profile, sperm morphology, toxicity.

\section{INTRODUCTION}

Adequate nutrition plays a crucial role in both maintenance of good health and longevity as there are hundreds of thousands of people, including children whose health becomes fragile due to the insufficiency of some food nutrients (WHO, 2000; WHO, 2003). Sufficiency in nutrient intake, 
especially of protein foods, fruits, vegetables and nuts seems to be governed by household affordability strength and the most vulnerable group are infants and pregnant/lactating mothers (Nkafamiya et al., 2006). Tropical seeds, either wild or cultivated offer a convenient but cheap means of providing nourishments in terms of vitamins, minerals, lipid, protein and carbohydrate content, especially in rural populations (Glew et al., 2005).

The value of the crude protein in Deterium senegalense is relatively low (about $12 \mathrm{~g} / 100 \mathrm{~g})$ seed powder but with correspondingly high protein values (Onyechi et al., 2007). Thus, the seeds have high food energy and can be used to supplement the daily energy intake. Detarium senegalense JF Gmelin (Caesalpinaceae) is a tree reaching height of about $36 \mathrm{~m}$ with buttressed bole and it is native to Tropical Africa. The common name is tallow tree and in South East of Nigeria, it is known as Offor. All parts of the tree are useful traditionally. Offor leaves are eaten as vegetable and are used locally as eye wash for conjunctivitis, enema for dysentery and wash for itch. The seeds are used as a thickener for soups and stews in Eastern Nigeria. They are given in the case of arrow poisoning. It is also used locally for the treatment of skin diseases (Sowemimo et al., 2001). Anthocyanidin alkaloid (2methoxyamine 3, 4, 5, 7- tetrahydroxy anthocynadine) with antibacterial activity has been isolated from the stem bark (Okwu and Uchegbu, 2009).

The fruits pulp is rich in vitamins (Diop, 2011). Soluble dietary fiber present in it is in the form of mucus, lignans and a water soluble non-starch polysaccharide has been reported in seed flour of the plant (Al-Shahib and Marshal, 2003). Incorporation of the seed flour into two meals, stew and bread in human study elicited lowering of blood glucose level in normal subjects and gum from the seed has been reported to have promising antidiabetic properties in rats (Adikwu et al., 2004). The thermophysical properties of the seed powder have been reported (Akinbode et al., 2012). The proximate analysis of the seed flour has been reported (Akpata and Miachi, 2001; Sowemimo et al., 2011) and the seed has been shown to be rich in carbohydrates and other nutrients.

The objective of this work was to evaluate the nutritional quality of DDS and compare it with soybeans in animal feed experiment. This paper reports for the first time, the nutritional evaluation of the DDS seed residue meal on growth, markers of both hepatotoxicity and nephrotoxicity, lipid peroxidation, tissue antioxidant levels, sperm counts and morphology as well as histopathology of liver, kidney and testes in male rats.

\section{MATERIALS AND METHODS} Source and preparation of DDS plant food

The mature seeds were purchased from Ojoo market, Ibadan and identified at the Herbarium of the Department of Botany, University of Ibadan, Ibadan Nigeria. The air dried seeds were ground using harmer mill in Department of Pharmacognosy, University of Ibadan and was defatted by subjecting it to Soxhlet extraction using nHexane for 6 hours in the Nutrition/Industrial Biochemistry Laboratory, University of Ibadan, Ibadan to obtain the defatted residue. This was dried in oven and stored for the formulation of animal feed.

\section{Feed formulation using DDS seed residue}

Normal protein diet was prepared using soybean (19\%), whole maize flour (Zea mays) (55\%), corn starch $(16.4 \%)$, palm oil $(5.2 \%)$ and salt/vitamin mix (4.4\%) was from SigmaAldrich Co. Ltd., Poole Dorset, UK. Same ingredients were used for test protein diet except soybeans was replaced with defatted Detarium senegalense residue which varied from $19 \%, 16 \%, 12 \%, 8 \%$ and $4.8 \%$ while the difference was made up using soybeans. Protein composition was $19 \%$ for all 
formulated feeds. Components of the mineral mix (Vitamin A 15,000,000 iu, vitamin D3 4,4000,000 iu, vitamin E 1,350 iu, vitamin K 4,350 mg, vitaminB2 4,350 mg, vitamin B6 2,350 mg, vitamin B12 11,350 mg, vitamin C $1,000 \mathrm{mg}$, nicotinamide $16,700 \mathrm{mg}$, calcium patothenate $5,350 \mathrm{mg}$, sodium sulphate $212,000 \mathrm{mg}, \mathrm{KCl} 87,000 \mathrm{mg}, \mathrm{MgSO}_{4} 12,000$ $\mathrm{mg}, \mathrm{ZnSO}_{4} 12,000 \mathrm{mg}, \mathrm{MnSO}_{4} 12,000 \mathrm{mg}$, Lysine hydrochloride $15,000 \mathrm{mg}$, Methionine $10,000 \mathrm{mg}$, Excipients QS $1,000 \mathrm{mg}$ ) distributed in Nigeria by Polons Agro Investment Limited and the different components of the diet were thoroughly mixed, made into pellets for easy handling by animals. Prepared feed was thoroughly oven dried to prevent mold growth and was stored in air tight bags at $4{ }^{\circ} \mathrm{C}$ to prevent microbial contamination and auto-oxidation of the oil (Oladiji et al., 2010).

\section{Proximate analysis of the feeds}

Feeds were analyzed for ash and mineral content using muffle furnace at 550 ${ }^{\circ} \mathrm{C}$ for $4 \mathrm{~h}$. Moisture content was determined by drying in the oven at $100{ }^{\circ} \mathrm{C}$ until a constant weight was obtained (at least $24 \mathrm{~h}$ ). Total dietary fiber was determined by an enzymatic gravimetric method, crude oil content was assayed by extraction with $n$ hexane in a Soxhlet extractor and nitrogen was determined by standard micro kjeldahl method using a digestion apparatus (AOAC, 2005). The crude protein content was thereafter calculated by multiplying nitrogen content by a factor of 5.71, which takes into account the non-protein nitrogen and has been approved for calculating the crude protein content. Moisture content was determined by drying to a constant weight at $100{ }^{\circ} \mathrm{C}$ for $24 \mathrm{~h}$.

\section{Animals and dietary treatments}

Thirty six male albino rats (Wistar strain) weighing between $60 \mathrm{~g}$ and $80 \mathrm{~g}$ were obtained from the animal house in the Department of Veterinary Physiology, University of Ibadan. On arrival, the rats were transferred and allowed to acclimatize for two weeks, been maintained on the standard normal diet (Ladokun Feeds, Ibadan) with water ad-libitum in the Biochemistry Department animal house under normal room temperature before the commencement of the experiment. Animals were distributed randomly into six different groups of six animals each. The control group received normal protein diet and the remaining five groups were fed experimental diet compounded using varying percentages of DDS seed residue. Group 1: Rats were fed normal protein diet daily for two months while groups 2-6 were fed compounded diet using $19 \%, 16 \%, 12 \%, 8 \%$ and $4.8 \%$ seed residue respectively for eight weeks.

\section{Sample collection for biochemical analysis}

Animals were sacrificed by cervical dislocation and blood was obtained using $2 \mathrm{ml}$ syringe by cardiac puncture into clean bottles and allowed to clot. These were spun at 3000 rpm for 10 minutes; the supernatant (serum) was removed and stored at $4{ }^{\circ} \mathrm{C}$. The liver and kidney were quickly removed, weighed, washed with $1.15 \% \mathrm{KCl}$, homogenized in 56 $\mathrm{mM}$ Tris- $\mathrm{HCl}$ buffer (pH 7.4) containing $1.15 \%$ potassium chloride and the homogenate was centrifuged at $10,000 \mathrm{rpm}$ for 15 minutes to obtain post mitochondrial fraction (PMF) at $4{ }^{\circ} \mathrm{C}$.

\section{Biochemical analysis}

The concentration of protein in the serum and PMF was determined using the method of Lowry et al. (1951) with bovine serum albumin (BSA) as standard. The extent of lipid peroxidation was determined by estimating the thiobarbituric acid reactive substances (TBARS) formed following the method of Varshney and Kale (1990). Superoxide dismutase (SOD) activity was assayed using the method of Misra and Fridovich (1972). The tissue homogenate (0.5 $\mathrm{ml}$ ) was mixed with ethanol and chloroform mixture, and then centrifuged. To the 
supernatant, $0.025 \mathrm{M}$ sodium pyrophosphate buffer ( $\mathrm{pH}$ 8.3), phenazine methosulphate, nitroblue tetrazolium and NADH were added and incubated at $30{ }^{\circ} \mathrm{C}$ for 90 seconds. The reaction was stopped by the addition of glacial acetic acid and mixed with $n$-butanol. The intensity of the chromogen in the $n$-butanol was measured at $560 \mathrm{~nm}$. Microsomal catalase (CAT) activity was determined by using hydrogen peroxide, briefly, the reaction mixture contained phosphate buffer $(0.01 \mathrm{M}$, $\mathrm{pH}$ 7.0), tissue homogenate and $2 \mathrm{M} \mathrm{H}_{2} \mathrm{O}_{2}$. The reaction was stopped by the addition of dichromate-acetic acid reagents (5\% potassium dichromate and glacial acetic acid were mixed in a ratio of 1:3) (Claiborne, 1989). Cholesterol was determined according to the method of Richmond (1973) by absorbance measurement at $490 \mathrm{~nm}$ when cholesterol reacts with $\mathrm{FeSO}_{4}$ in glacial acetic acid is treated with $\mathrm{H}_{2} \mathrm{SO}_{4}$. Triglycerides were estimated after enzymatic hydrolysis with lipases by measuring quinoneimine formed from hydrogen peroxide, 4-aminophenazone and 4-chlorophenol under catalytic influence of peroxidase. Serum creatinine level was estimated by the method of Bartels et al. (1972) by the amount of coloured complex formed with picric acid at $492 \mathrm{~nm}$. Serum urease was estimated at $546 \mathrm{~nm}$ using the amount of urea in serum that is hydrolyzed to ammonia by urease (Fawcett et al., 1960). Enzyme parameters for aspartate aminotransferase (AST) and alanine amonitransferase (ALT) were assayed by the method of Reitman and Frankel (1957).

\section{Sperm analysis}

Sperm analysis was done include motility, live-dead count, sperm morphology and concentration. Sperm motility was done by microscopic examination using drop of semen incubated using Tris/citric acid/fructose medium. Semen suspension stained with $1 \%$ eosin $\mathrm{B}$ and $5 \%$ nigosin was examined under the microscope and percentage of stained and unstained cell was estimated. Sperm morphology was studied under the microscope at high magnification and estimation of daily sperm count was done using heamacytometer.

\section{Statistical analysis}

Values were expressed as the mean \pm S.D of six animals. Data were analysed with one-way analysis of variance (ANOVA). Thereafter, the post-hoc Duncan multiple tests for analysing biochemical data using SPSS (10.0) statistical software were done. $P$ values $<0.05$ were considered statistically significant.

\section{RESULTS}

Proximate analysis

The results obtained for proximate analysis of soya bean, DDS and the nondefatted DS seed flours are shown on Table 1. Soybean protein had $17.78 \%$ crude protein content and this was about $4 \%$ higher than those from non-deffated and DDS. The percentage protein in non-deffated and DDS were approximately the same. The nondefatted DS seed flour had approximately $8 \%$ fat higher than the DDS while DDS had approximately $7 \%$ carbohydrate higher than the non-defatted DS, protein content was similar in both but DDS had slightly more ash and fibre content.

\section{Body and organ weights}

Changes in body weight caused by feeding animals with soya bean and varying percentages of DDS feed for twenty eight days is shown on Table 2. All animals on test diets gained weight with the animals on $19 \%$ DDS (Group T2) having the least increment with $41 \%$ and T6 with only $4.8 \%$ DDS had the highest with $69 \%$ increase in body weight. T6 rats had slightly enlarged liver. T5 and T4 on 12 and $8 \%$ DDS augmented to $19 \%$ using soybean powder had similar increase in body weight as control rats (T1) but liver and kidney weights were slightly lower. 


Sperm quality and morphological
characteristics

Tables 3 and 4 respectively have data obtained for sperm quality and morphological characteristics on rats after twenty eight days feeding on DDS. Sperm motility was lowest in animals in groups T2 and T3 but there were no significant $(\mathrm{P}>0.05)$ differences in the groups. The live/dead cell count were similar in all test animals, however the sperm count was significantly $(\mathrm{P}<0.05)$ lower in $\mathrm{T} 2$ on $19 \%$ DDS compared to T1 on $19 \%$ soybean. $\mathrm{T} 2$ had significantly $(\mathrm{P}<0.05)$ increased bent tail, T2 and T3 had significantly increased curved tail while only $\mathrm{T} 4$ has significantly increased bent-mid piece. T6 had significantly $(\mathrm{P}<0.05)$ lowered head less tail compared to both $\mathrm{T} 1$ and T2. Generally, all test animals on DDS or DDS supplemented feeds had more total abnormal sperm cells compared to control (T1).

\section{Effect of DDS feeding on oxidative stress parameters}

Liver and kidney tissue markers of oxidative stress are shown on Tables 5 and 6 respectively. Feeding rats $19 \%$ DDS diet for twenty eight days caused over $200 \%$ increase in GSH, 250\% increase in GST and 50\% increase in GPx. Rats in group T6 on $4.8 \%$ DDS had similar liver GPx values as T1 on $19 \%$ soya bean (Table 5). SOD was only slightly increased but T4-6 had lower SOD levels while in T6 it was significantly decreased compared to T1. CAT levels were lower in rats on DDS compared to $\mathrm{T} 1$ but kidney CAT levels in T2 was higher than those of rats on lower percentage of DDS in their feed. MDA increased in the liver of rats on DDS diet, T6 and T1had similar MDA values but in the kidney MDA vales decreased when compared to $\mathrm{T} 1$.

Effect of DDS feeding on serum lipid profile parameters and tissue protein content

Table 7 has data for lipid profile parameters and protein concentration in liver and kidney. Triglyceride (Tg) increased significantly in T1, there was over $200 \%$ decrease in serum $\mathrm{Tg}$ in group $\mathrm{T} 2$ rats on $19 \%$ DDS diet. Other rats on DDS had lower serum $\mathrm{Tg}$ values compared to T1. Total cholesterol increased significantly in T2 and T3 on 19 and $16 \%$ DDS respectively, while only T5 had significantly decreased total cholesterol levels compared to T2. HDL-c was almost $100 \%$ higher in T2 compared to control and T2 had the highest HDL-c values $\mathrm{n}$ the treatment groups. LDL-c was significantly increased in all rats on DDS compared to $\mathrm{T} 1$. Liver protein concentration increased in T4-T6 but the kidney protein concentration decreased from T2-T5.

\section{Effect of DDS feeding on markers of Tissue toxicity}

Effect of DDS feeding on markers of tissue damage: Data obtained for serum markers of tissue injury are show on Table 8 . AST increased in T3-T6 compared to T2 and $\mathrm{T} 1$. ALT decreased in T2 but not significant, however, it was higher significantly in groups T3-T6 compared to T2 and T1. Serum urea levels increased by over $100 \%$ in $\mathrm{T} 2$ compared to $\mathrm{T} 1$ and were much higher in groups T3-T6 respectively.

\section{Tissue histopathology changes caused by DDS feeding}

Photomicrograph of liver, kidney and Testes of rats on DDS feeding for 28 days: Photomicrograph of haematoxylin and eosin stained liver, kidney and testes sections are shown in Figures 1, 2 and 3 respectively. There were no visible lesions in T1 liver, but T2 had portal congestion and mild cellular infiltration. There was diffuse vascular congestion and mild portal congestion in the other groups but all groups of animals had kidney and testes tissues with no visible lesions. 
S.O. NWOZO et al. / Int. J. Biol. Chem. Sci. 10(3): 928-943, 2016

Table 1: Proximate analysis of compounded feeds.

\begin{tabular}{lcccccc}
\hline Samples & \% Protein & \% Carbohydrate & \% Moisture content & \% Fat & \% Ash content & \% Crude Fibre \\
\hline Normal protein diet & 17.78 & 72.16 & 4.87 & 3.88 & 1.21 & 1.13 \\
Defatted DS residue & 13.35 & 70.21 & 12.08 & 2.06 & 2.31 & 1.98 \\
Non-defatted DS & 13.36 & 63.22 & 11.57 & 10.01 & 1.87 & 1.96 \\
\hline
\end{tabular}

Table 2: Effect of feeding with DDS seed residue on body weights and absolute organ weights for eight weeks in Wistar male rats.

\begin{tabular}{lccccc}
\hline Animal groups & $\begin{array}{c}\text { Initial body } \\
\text { weight }(\mathbf{g})\end{array}$ & $\begin{array}{c}\text { Final body } \\
\text { weight }(\mathbf{g})\end{array}$ & \% Increase & Liver weight (g) & $\begin{array}{c}\text { Kidney weight } \\
(\mathbf{g})\end{array}$ \\
\hline T1 & $64.17 \pm 4.92$ & $170.83 \pm 24.58^{\mathrm{b}}$ & 62 & $4.83 \pm 0.521^{\mathrm{b}}$ & $0.98 \pm 0.180^{\mathrm{b}}$ \\
T2 & $68.75 \pm 8.54$ & $116.25 \pm 11.09^{\mathrm{a}}$ & 41 & $2.74 \pm 0.191 \mathrm{a}$ & $0.61 \pm 0.059^{\mathrm{a}}$ \\
T3 & $69.17 \pm 8.01$ & $150.00 \pm 15.81^{\mathrm{b}}$ & 54 & $4.32 \pm 0.366^{\mathrm{b}}$ & $0.78 \pm 0.032^{\mathrm{a}, \mathrm{b}}$ \\
T4 & $63.75 \pm 4.79$ & $158.33 \pm 14.43^{\mathrm{b}}$ & 60 & $3.94 \pm 0.657^{\mathrm{b}}$ & $0.71 \pm 0.100^{\mathrm{a}}$ \\
T5 & $65.00 \pm 6.32$ & $168.33 \pm 29.44^{\mathrm{b}}$ & 61 & $4.35 \pm 1.21^{\mathrm{b}}$ & $0.89 \pm 0.120^{\mathrm{b}}$ \\
T6 & $65.00 \pm 5.00$ & $208.33 \pm 14.43^{\mathrm{a}, \mathrm{b}}$ & 69 & $6.08 \pm 0.332^{\mathrm{a}, \mathrm{b}}$ & $0.99 \pm 0.067^{\mathrm{b}}$ \\
\hline \multicolumn{4}{l}{ Data are mean + S.D of six rats ${ }^{\mathrm{a}}$ Significant when compared with control and ${ }^{\mathrm{b}}$ Significant when compared to $19 \%$ DS residue group at $\mathrm{p}<0.05$}
\end{tabular}

D1: 
S.O. NWOZO et al. / Int. J. Biol. Chem. Sci. 10(3): 928-943, 2016

Table 3: Effect of DDS seed residue feeding for eight weeks on sperm quality parameters in male rats.

\begin{tabular}{|c|c|c|c|}
\hline Animal groupings & Sperm motility & Live or dead count & Sperm count \\
\hline T1 & $63.33 \pm 5.77$ & $95.33 \pm 4.62$ & $84.50 \pm 6.36^{b}$ \\
\hline $\mathrm{T} 2$ & $53.33 \pm 5.77$ & $94.33 \pm 4.04$ & $77.00 \pm 7.55^{\mathrm{a}}$ \\
\hline $\mathrm{T} 3$ & $53.33 \pm 11.54$ & $87.50 \pm 3.54$ & $85.00 \pm 4.24$ \\
\hline $\mathrm{T} 4$ & $60.00 \pm 10.00$ & $94.33 \pm 4.04$ & $79.00 \pm 1.41$ \\
\hline T5 & $56.67 \pm 5.77$ & $94.33 \pm 4.04$ & $79.50 \pm 0.71$ \\
\hline T6 & $65.00 \pm 7.07$ & $94.33 \pm 4.04$ & $72.33 \pm 7.51$ \\
\hline
\end{tabular}

T1: control, T2: 19\%, T3: 16\%, T4: 12\%, T5: $8 \%$ and T6: $4.8 \%$.

Table 4: Effect of DDS seed residue feeding for eight weeks on morphological characteristics of spermatozoa in the testes of wistar male rats.

\begin{tabular}{lcccccc}
\hline Morphological characteristics & T1 & T2 & T3 & T4 & T5 & T6 \\
\hline Tail less head & $5.00 \pm 1.00$ & $5.33 \pm 0.58$ & $5.33 \pm 0.58$ & $5.00 \pm 1.00$ & $5.50 \pm 0.71$ & $5.50 \pm 0.71$ \\
Head less tail & $4.33 \pm 1.15$ & $4.33 \pm 1.53$ & $4.00 \pm 1.00$ & $4.67 \pm 1.53$ & $3.67 \pm 0.58$ & $2.00 \pm 1.00^{\mathrm{ab}}$ \\
Rudimentary tail & $2.00 \pm 1.00$ & $1.67 \pm 1.15$ & $2.00 \pm 1.00$ & $2.00 \pm 1.00$ & $2.00 \pm 1.00$ & $2.67 \pm 0.58$ \\
Bent tail & $7.33 \pm 1.53^{\mathrm{b}}$ & $10.67 \pm 0.57^{\mathrm{a}}$ & $10.00 \pm 1.41$ & $9.50 \pm .71$ & $9.50 \pm 0.71$ & $8.5 \pm 0.71$ \\
Curved tail & $7.33 \pm 1.15^{\mathrm{b}}$ & $10.33 \pm 1.15^{\mathrm{a}}$ & $9.67 \pm 1.15^{\mathrm{a}}$ & $9.33 \pm 1.53$ & $9.50 \pm 0.71$ & $9.00 \pm 1.41$ \\
Curved mid-piece & $8.00 \pm 1.00$ & $9.00 \pm 2.00$ & $8.67 \pm 1.53$ & $9.67 \pm 1.55$ & $9.67 \pm 1.53$ & $8.67 \pm 1.55$ \\
Bent mid-piece & $8.00 \pm 1.00$ & $9.67 \pm 1.53$ & $9.00 \pm 1.00$ & $10.33 \pm 0.58^{\mathrm{a}}$ & $9.00 \pm 1.00$ & $8.33 \pm 1.15$ \\
Looped tail & $1.67 \pm 1.15$ & $2.00 \pm 1.00$ & $1.67 \pm 1.15$ & $2.00 \pm 1.00$ & $2.00 \pm 1.00$ & $2.00 \pm 1.00$ \\
Total abnormal sperm cell & $43.67 \pm 2.89$ & $53.00 \pm 6.08$ & $51.00 \pm 6.07$ & $51.67 \pm 3.21$ & $52.00 \pm 6.00$ & $48.00 \pm 7.94$ \\
\hline \multicolumn{7}{c}{ Data are mean \pm S.D of six rats ; ${ }^{\mathrm{a}}$ Significant when compared with control and ${ }^{\mathrm{b}}$ Significant when compared to $19 \%$ DS residue group at p<0.05. }
\end{tabular}

T1: control, T2: 19\%, T3: 16\%, T4: 12\%, T5: $8 \%$ and T6: $4.8 \%$. 
Table 5: Effect of DDS seed residue on GSH, GST and GPx activities in the liver and kidney after eight weeks of feeding in male Wistar rats.

\begin{tabular}{lcccccc}
\hline Treatments & $\begin{array}{c}\text { Liver GSH } \\
(\boldsymbol{\mu g} / \mathbf{m l})\end{array}$ & $\begin{array}{c}\text { Kidney GSH } \\
(\boldsymbol{\mu g} / \mathbf{m l})\end{array}$ & $\begin{array}{c}\text { Liver GST } \\
(\boldsymbol{\mu g} / \mathbf{m l})\end{array}$ & $\begin{array}{c}\text { Kidney GST } \\
(\boldsymbol{\mu g} / \mathbf{m l})\end{array}$ & $\left.\begin{array}{c}\text { Liver GPx }(\text { unit/mg) } \\
\text { T1 }\end{array} 6^{\mathrm{b}}\right)$ & $\begin{array}{c}\text { Kidney GPx } \\
(\mathbf{u n n i t s} / \mathbf{m g})\end{array}$ \\
T2 & $16.03 \pm 1.07^{\mathrm{b}}$ & $7.66 \pm 0.90$ & $0.30 \pm 0.13^{\mathrm{b}}$ & $0.50 \pm 0.32$ & $129.87 \pm 33.26^{\mathrm{b}}$ & $214.47 \pm 74.64$ \\
$\mathrm{~T} 3$ & $8.91 \pm 1.92$ & $0.83 \pm 0.17^{\mathrm{a}}$ & $0.55 \pm 0.25$ & $180.87 \pm 19.96^{\mathrm{a}}$ & $248.93 \pm 99.93$ \\
T4 & $13.26 \pm 1.07^{\mathrm{a}, \mathrm{b}}$ & $6.45 \pm 1.37$ & $0.86 \pm 0.19^{\mathrm{a}}$ & $0.71 \pm 0.30$ & $177.46 \pm 19.4^{\mathrm{a}}$ & $294.86 \pm 15.32$ \\
T5 & $7.30 \pm 0.33^{\mathrm{b}}$ & $10.32 \pm 0.45^{\mathrm{a}}$ & $0.84 \pm 0.35^{\mathrm{a}}$ & $0.51 \pm 0.19$ & $142.70 \pm 44.81$ & $237.91 \pm 71.35$ \\
T6 & $9.04 \pm 0.79^{\mathrm{a}, \mathrm{b}}$ & $9.00 \pm 1.82^{\mathrm{a}}$ & $1.04 \pm 0.14^{\mathrm{a}}$ & $0.73 \pm 0.48$ & $177.12 \pm 26.60$ & $158.83 \pm 33.05$ \\
\hline
\end{tabular}

Data are mean \pm S.D of six rats ; ${ }^{a}$ Significant when compared with control and ${ }^{b}$ Significant when compared to $19 \%$ DS residue group at $\mathrm{p}<0.05$.

T1: control, T2: $19 \%$, T3: 16\%, T4: 12\%, T5: $8 \%$ and T6: $4.8 \%$

Table 6: Effect of DDS seed residue on SOD, CAT activities and lipid peroxidation levels in the liver and kidney after eight weeks of feeding in male Wistar rats.

\begin{tabular}{lccccc}
\hline Treatments & $\begin{array}{c}\text { Liver SOD } \\
\text { (unit/mg } \\
\text { protein) }\end{array}$ & $\begin{array}{c}\text { Kidney SOD } \\
\text { (unit/mg } \\
\text { protein) }\end{array}$ & $\begin{array}{c}\text { Liver CAT (units/mg } \\
\text { protein) }\end{array}$ & $\begin{array}{c}\text { Kidney CAT (units/ } \\
\text { mg protein) }\end{array}$ & $\begin{array}{c}\text { Liver MDA } \\
\text { (units/mg protein) }\end{array}$ \\
\hline T11 & $1.06 \pm 0.28$ & $1.13 \pm 0.42$ & $640.44 \pm 50.32$ & $811.21 \pm 136.01$ & $0.15 \pm 0.01$ \\
(unit/mg protein) & \\
T2 & $1.10 \pm 0.22$ & $1.13 \pm 0.52$ & $601.62 \pm 65.72$ & $866.47 \pm 45.82$ & $0.17 \pm 0.08$ \\
T3 & $1.08 \pm 0.21$ & $1.87 \pm 0.11^{\mathrm{a}, \mathrm{b}}$ & $590.46 \pm 87.33$ & $415.67 \pm 45.91$ & $0.18 \pm 0.06$ \\
T4 & $0.82 \pm 0.34$ & $1.07 \pm 0.54$ & $374.04 \pm 28.09^{\mathrm{a}, \mathrm{b}}$ & $541.26 \pm 202.82^{\mathrm{a}}$ & $0.18 \pm 0.08$ \\
T5 & $0.76 \pm 0.20$ & $0.85 \pm 0.19$ & $593.46 \pm 76.91$ & $521.51 \pm 114.87^{\mathrm{a}}$ & $0.17 \pm 0.05$ \\
T6 & $0.44 \pm 0.07^{\mathrm{a}, \mathrm{b}}$ & $0.53 \pm 0.12$ & $357.38 \pm 45.57^{\mathrm{a}, \mathrm{b}}$ & $307.14 \pm 28.34$ & $0.19 \pm 0.06$ \\
\hline
\end{tabular}

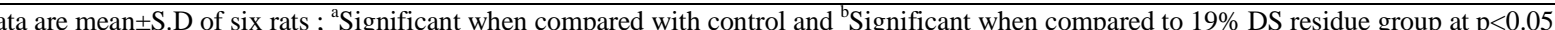

T1: control, T2: 19\%, T3: 16\%, T4: 12\%, T5: $8 \%$ and T6: $4.8 \%$. 
Table 7: Effect of DDS seed residue based diet on serum lipid profile parameters, kidney and liver total protein after eight weeks of feeding in male Wistar rats.

\begin{tabular}{|c|c|c|c|c|c|c|}
\hline $\begin{array}{l}\text { Animal treatment } \\
\text { group }\end{array}$ & $\mathrm{Tg}(\mathrm{mmol} / \mathrm{I})$ & Tc $(\mathrm{mmol} / \mathrm{I})$ & $\begin{array}{l}\text { HDLc } \\
(\mathrm{mmol} / \mathrm{I})\end{array}$ & $\begin{array}{l}\text { LDLc } \\
(\mathrm{mmol} / \mathrm{I})\end{array}$ & $\begin{array}{l}\text { Liver protein } \\
(\mu \mathrm{g} / \mathrm{ml})\end{array}$ & $\begin{array}{l}\text { Kidney protein } \\
(\mu \mathrm{g} / \mathrm{ml})\end{array}$ \\
\hline T1 & $2.98 \pm 0.23^{b}$ & $1.83 \pm 0.38$ & $1.23 \pm 0.14^{\mathrm{b}}$ & $1.46 \pm 0.29^{b}$ & $1.37 \pm 0.32$ & $2.01 \pm 0.75$ \\
\hline $\mathrm{T} 2$ & $1.07 \pm 0.35^{\mathrm{a}}$ & $2.35 \pm 0.53$ & $2.03 \pm 0.09^{\mathrm{a}}$ & $2.68 \pm 0.45^{\mathrm{a}}$ & $1.35 \pm 0.20$ & $1.77 \pm 0.42$ \\
\hline $\mathrm{T} 3$ & $2.03 \pm 0.31^{\mathrm{a}, \mathrm{b}}$ & $2.66 \pm 0.54^{\mathrm{a}}$ & $1.20 \pm 0.10$ & $3.73 \pm 0.62^{\mathrm{a}, \mathrm{b}}$ & $1.45 \pm 0.3$ & $0.79 \pm 0.04^{\mathrm{a}, \mathrm{b}}$ \\
\hline $\mathrm{T} 4$ & $2.30 \pm .10^{\mathrm{a}, \mathrm{b}}$ & $2.07 \pm 0.35$ & $1.10 \pm 1.8$ & $2.70 \pm 0.10^{\mathrm{a}}$ & $1.73 \pm 0.48$ & $1.41 \pm 0.71$ \\
\hline $\mathrm{T} 5$ & $2.00 \pm 0.12^{\mathrm{a}, \mathrm{b}}$ & $1.36 \pm 0.29^{\mathrm{b}}$ & $0.95 \pm 0.16^{\mathrm{a}}$ & $1.80 \pm 0.27^{\mathrm{b}}$ & $1.52 \pm 0.32$ & $1.74 \pm 0.49$ \\
\hline T6 & $1.50 \pm 0.14^{\mathrm{a}}$ & $1.95 \pm 0.35$ & $0.83 \pm 0.15^{\mathrm{a}}$ & $2.14 \pm 0.32^{\mathrm{a}}$ & $2.11 \pm 0.15^{\mathrm{a}, \mathrm{b}}$ & $2.45 \pm 0.11$ \\
\hline
\end{tabular}

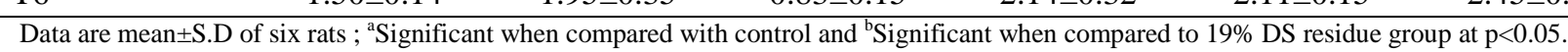

T1: control, T2: 19\%, T3: 16\%, T4: 12\%, T5: $8 \%$ and T6: 4.8\%. Tg: triglyceride, Tc: total cholesterol

Table 8: Effect of DDS seed residue on serum AST, ALT and urea levels after eight weeks of feeding in male Wistar rats.

\begin{tabular}{llll}
\hline Animal treatment group & AST $(\mathbf{U} / \mathbf{I})$ & ALT $(\mathbf{U} / \mathbf{I})$ & Urea $(\mathbf{m g} / \mathbf{d l})$ \\
\hline T1 & $90.67 \pm 3.05$ & $26.25 \pm 1.26^{\mathrm{b}}$ & $0.43 \pm 0.19$ \\
T2 & $90.00 \pm 7.07$ & $23.21 \pm 2.53$ & $1.03 \pm 0.020$ \\
T3 & $104.00 \pm 1.63^{\mathrm{a}, \mathrm{b}}$ & $31.67 \pm 1.83^{\mathrm{a}, \mathrm{b}}$ & $1.50 \pm 0.83^{\mathrm{a}}$ \\
T4 & $129.67 \pm 6.51^{\mathrm{a}, \mathrm{b}}$ & $35.45 \pm 1.39^{\mathrm{a}, \mathrm{b}}$ & $2.03 \pm 0.52^{\mathrm{a}, \mathrm{b}}$ \\
T5 & $112.50 \pm 6.24^{\mathrm{a}, \mathrm{b}}$ & $35,12 \pm 1.16^{\mathrm{a}, \mathrm{b}}$ & $2.35 \pm 0.37^{\mathrm{a}, \mathrm{b}}$ \\
T6 & $121.50 \pm 4.95^{\mathrm{a}, \mathrm{b}}$ & $32.41 \pm 0.13^{\mathrm{a}, \mathrm{b}}$ & $1.68 \pm 0.19^{\mathrm{a}}$ \\
\hline
\end{tabular}

Data are mean \pm S.D of six rats : ${ }^{\mathrm{a}}$ Significant when compared with control and ${ }^{\mathrm{b}}$ Significant when compared to $19 \%$ DS residue group at $\mathrm{p}<0.05$. T1: control, T2: 19\%, T3: 16\%, T4: 12\%, T5: $8 \%$ and T6: $4.8 \%$. 

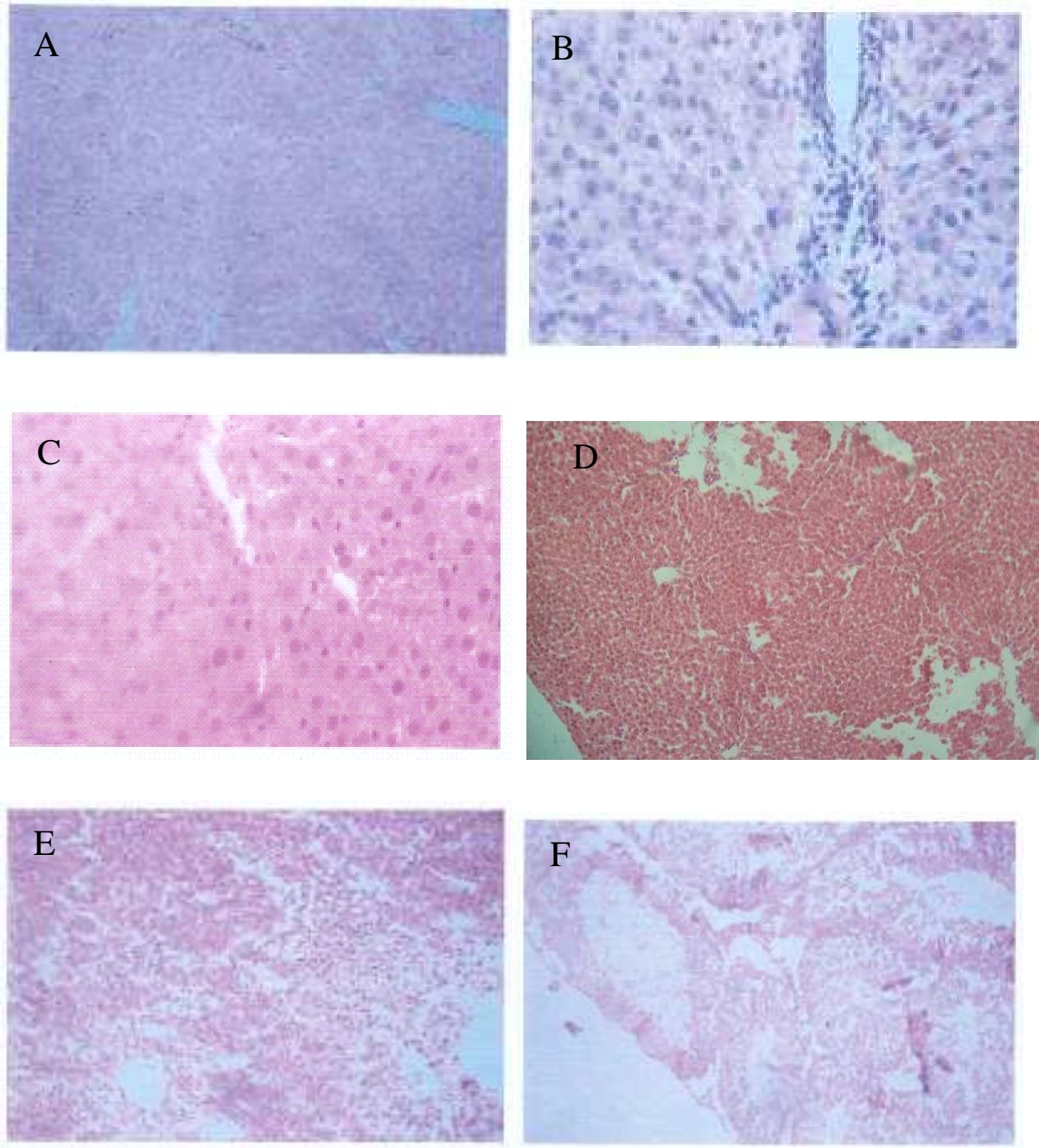

Figure 1: Histological examination of rat livers stained with hematoxylin and eosin (H\&E). (A) Control rats fed on normal protein diet showing no visible lesion; (B) Rats fed on $19 \%$ seed residue showing portal congestion and mild cellular infiltration; (C) Rats with 16\% D.S showing diffuse vascular degeneration; (D) Rat fed $12 \%$ showing no visible lesions; (E) Rats fed with $8 \%$ D.S showing diffuse vascular degeneration and mild portal congestion; (F) Rats fed with $4.8 \%$ D.S showing moderate portal cellular infiltration by mononuclear cells and very mild vacuolar degeneration and necrosis.
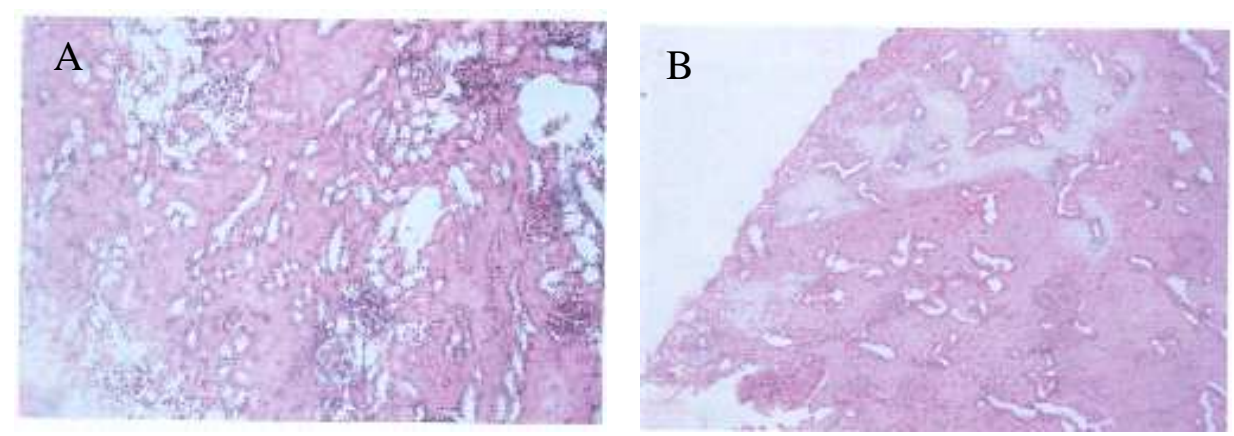

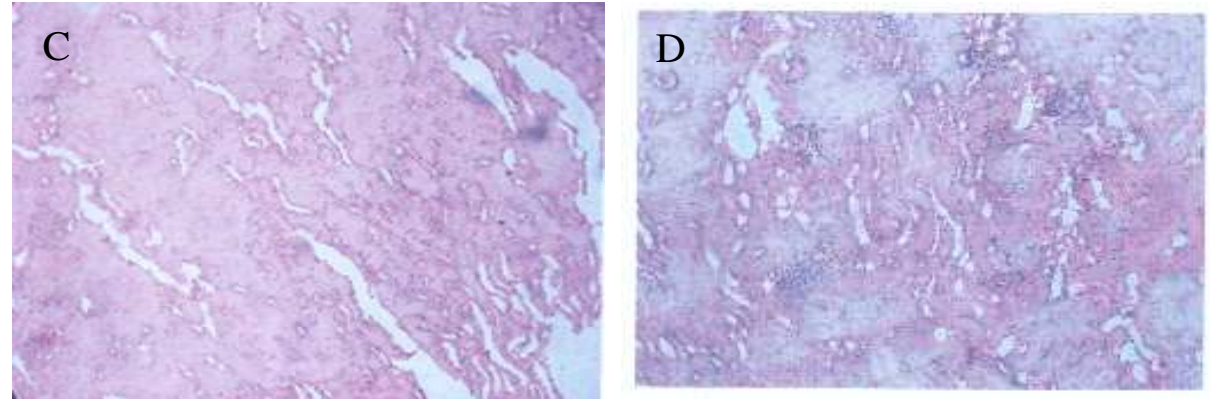

Figure 2: Histological examination of rat kidney section stained with hematoxylin and eosin (H\&E). (A) Rats fed on 19\% D.S showing no visible lesion; (B) Rats fed on 16\% D.S showing no visible lesion; (C) Rats fed with $12 \%$ D.S showing no visible lesion; (D) Rats fed with $4.8 \%$ showing no visible lesion.
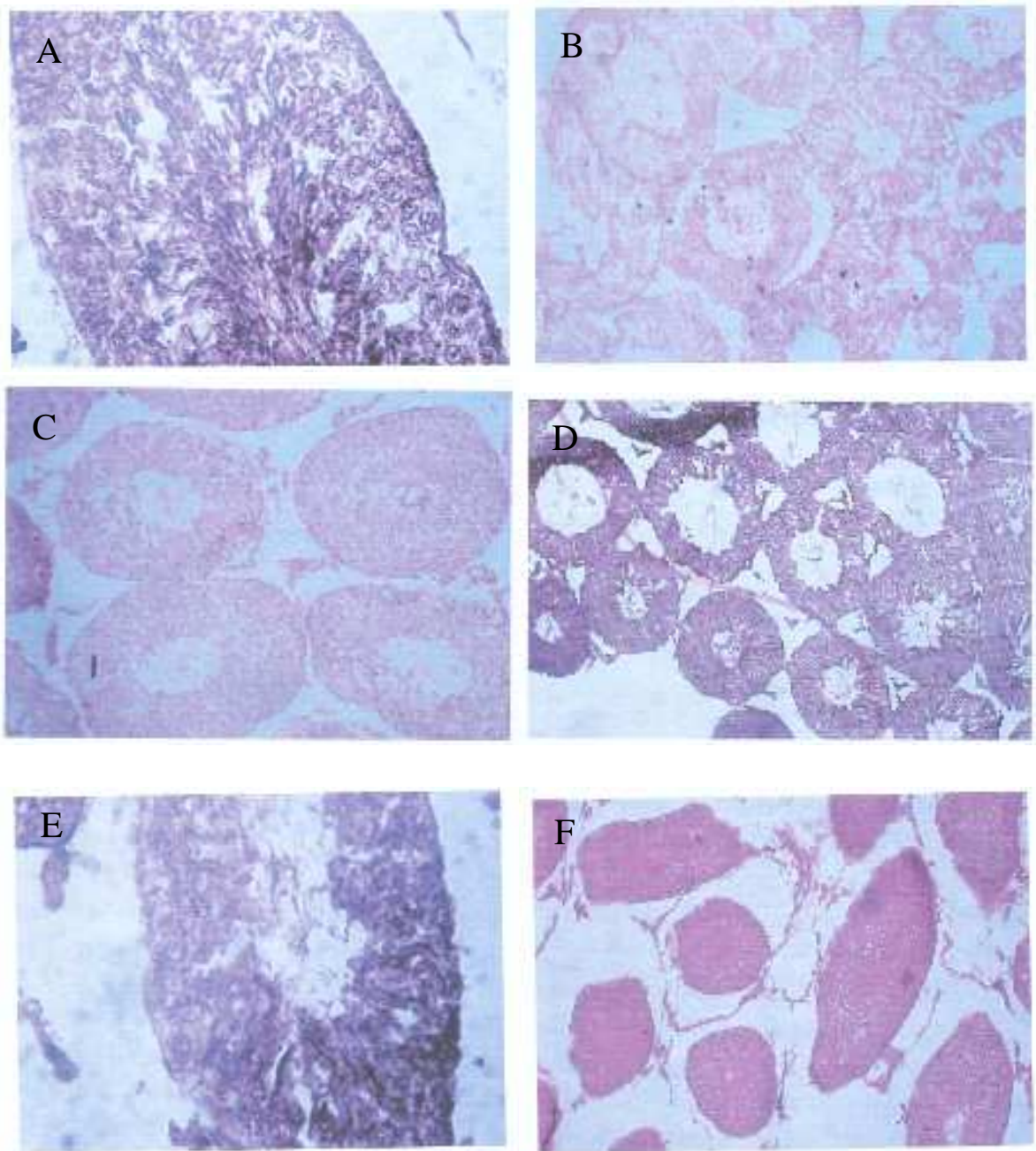

Figure 3: Histological examination of rat testes section stained with hematoxylin and eosin (H\&E). (A) Rats fed with normal protein diet showing no visible lesion; (B) Rats fed with 19\% D.S showing no visible lesion; (C) Rats fed with $16 \%$ D.S showing no visible lesion;

(D) Rats fed with $12 \%$ D.S showing no visible lesion; (E) Rats fed with $8 \%$ D.S showing no visible lesion; (F) Rats fed with 4.8\% D.S showing no visible lesion. 


\section{DISCUSSION}

Detarium senegalense has been implicated as a good source of nutrients with high protein content and it is commonly used as soup thickener and this informed us to investigate the effect of continual consumption of the defatted seed residue in male Wistar rats for eight weeks. The proximate analysis (Table 1) DDS residuebased diet had lower protein content compared to the control diet (Soybeans) by approximately 5\% (Group T2), hence we had formulated diets with different percentages of DDS $(16 \%, 12 \%, 8 \%$ and $4.8 \%)$ augmented with soybean for animals in groups T3, T4, T5 and T6, so as to evaluate the effect of supplementation as well. Proximate analysis only provides information on the estimated amount of carbohydrate, crude lipid, crude protein, crude fiber, ash and moisture content in the diet but biochemical utilization of the feeds in the body. Biochemical constituents of serum, tissue and tissue histology could be used to assess the quality of the nutrients present in the diets. D. senegalense is richer in carbohydrate than soybean and fat content of whole soybean flour is higher than that in the DDS seed residue. There was no loss in psychomotor activity, no deaths in the eight weeks feeding duration and there were no changes in feed pattern in both control animals and those on DDS in this study. Animals were allowed free access to water and food and both activities increased with increasing age of rats. Water is an essential macro nutrient to life since it is the most and has been shown to be necessary for growth and development. Any factor influencing water intake will also affect feed consumption (Oladiji et al., 2007). Intake of feed and water increased in all groups of animals in this study and enhancement in water intake will also increase feed consumption which is an indicator of acceptability of feed to the taste and appetite of the animals.

Test diet using D. senegalense had approximately $4.5 \%$ and $1.5 \%$ lowered protein and fat contents respectively compared to soybeans. The result of proximate content, especially for protein is at variance with Sowemimo et al. (2011) who obtained percentage protein of $7.23 \%$. However, the dehauled seed has been reported to have $37.1 \%$ crude protein and $15 \%$ crude fat (Akpata and Miachi, 2001). Species differences, handling and environmental factors might have contributed to this disparity. Furthermore, there was a significant decrease in final body weights of rats fed test diets for eight weeks, especially at the highest percentage of tested diet (19\%) T2 compared to control (T1) (Table 2). We observed a $62 \%$ increase in the body weight of rats fed with soybean compounded feed (T1) control group compared to $19 \%$ DDS seed residue based feed group T2 with only $41 \%$ increase in body weight, despite the animals having similar weights at commencement of feeding experiment. Absolute kidney weight was reduced in $\mathrm{T} 2$ on the highest percentage, indicating that DS is not nephrotoxic (Saramma and Padmaja, 2013). Similarly, the liver weight was significantly decreased in T2 compared to control. This might be attributed to reduced body weight increase in DDS seed residue fed rats for based feed as well as the lowered protein content of DDS feed compared to soybean (Table 1). Furthermore, animals in T3 to T6 which had 16\%, 12\%, 8\% and $4.8 \%$ DDS seed residue feed augmented with soybean flour had increased body weight, with T6 having the highest body weight gain and visceral organs also increased. Fat content of the $19 \%$ soybean flour diet was also slightly increased compared to defatted seed flour (Table 1) and fats might increase absorption of protein and other nutrients (Matos et al., 2005; Hartvigsen et al., 2007).

DDS seed residue-based diet for eight weeks did not significantly affect in percentage viability and motility of sperm compared to control on soybean flour based diet but there was a significant decrease in sperm count of group T2 rats wholly on DDS seed residue as protein source, while slight reduction was observed in the animal groups whose diet was supplemented with soybean flour (Table 3). The more statistically 
observed variations in sperm morphology were headless tail, bent tail, curved tail and bent mid piece and these were increased in groups T2 to T6 on DDS seed residue based diet for eight weeks. Oxidative stress has been implicated in the aetiology of defective sperm function through induction of plasma membrane peroxidative damage (Sharmaa and Argawal, 1996; Agarwal and Saleh, 2002; Vernet et al., 2004).

DDS seed residue feeding for eight weeks in this study elicited oxidative stress in the liver (Tables 5 and 6). There was significant increase in values of GSH, GST and GPx in the liver, elevated values in CAT, SOD and MDA $n$ the liver tissue, while there was significant decreased in the kidney. Lipid peroxidation, measured in this study by assaying MDA is a well-established mechanism of cellular injury in both plants and animals, and is used as an indicator of oxidative stress in cells and tissues (Adejuwon et al., 2014; Owoeye and Farombi 2015). When this process occurs in biological membrane, obviously alteration of structural, organization and enzyme function may result. The noticeable increase in the activities of the liver GSH, GST, GPx, CAT, SOD levels in all the treated groups may be due continual DDS feeding for eight weeks eliciting oxidative stress in the liver and the activities of the respective antioxidant increased to counteract it. GSH is one of the antioxidant enzymes that act as the first line of defence against prooxidant stress. In the kidney, DDS feeding extracts improved the antioxidant status considerably as reflected by low MDA and decrease in the antioxidants measured.

There was an insignificant elevation of serum total cholesterol (TCHOL), significant increase in both low and high density lipoprotein (LDLc and HDLc), and a significant decrease in triglycerides in the DDSR fed rats. Elevated levels of LDLc have been pointed out as one of the risk factors for the development of atherosclerosis and related cardiovascular diseases (Getz and Reardon, 2006). Furthermore, a high serum triglyceride level is also an important risk factor as it influences lipid deposition in the blood vessels and clotting mechanisms (Harnafi et al., 2009).

In the other test groups on varying proportions of both test diet and soybean, the animals had elevated triglyceride levels, lowered HDLc compared to T2. LDLc was higher in groups T3 and T4 with 16\% and 12\% DDS seed residue based diet and this was significantly higher compared to control. Alterations in levels of serum lipids in animals offer information on the effect of diet on lipid metabolism as well as predisposition to coronary heart diseases (Visavadiya and Narasimacharya, 2005; Abolaji et al., 2007; Nwozo et al., 2011). Serum total cholesterol level of the animals on 19\% DDS seed residue based feed was increased, while HDLc was significantly increased in the same group (T2). HDLc is essential in the transportation of cholesterol from tissues to the liver where it is metabolized (Lacko et al., 2000) and it is considered as good cholesterol with antiatherogenic properties. HDLc constitutes a protective factor against cardiovascular diseases. Thus, the increase in HDLc and decrease in triglyceride levels of the animals fed with DDS seed residue based feed for 8 weeks could reduce susceptibility to cardiovascular disease.

Serum levels of alanine

aminotransferase (ALT), aspartate aminotransferase (AST) and urea levels are shown on Table 5. AST and ALT are useful biomarkers to predict possible tissue toxicity. Transaminases play an important role in protein and amino acid metabolism in hepatocytes and striated muscle cells and biochemical regulation of amino acid pool by providing necessary intermediates for gluconeogenesis. However, when cells are injured or necrosis occurs, these enzymes may leak or escape from these cells into the blood stream, where their present activities are consequently increased. Therefore, the determination of these transaminases in the serum is often used as one of the essential marker of liver damage (Rahman et al., 2001; Shahjahan et al., 2004). This is because they 
are cytoplasmic in location and are released into circulation after cellular damage (Saramma and Padmaja, 2013). Serum AST was slightly reduced, while ALT was significantly decreased in $\mathrm{T} 2$ but both parameters were significantly elevated in both control and other groups on both soybean and DDS seed residue feed groups for 8 weeks. These observations imply alterations in integrity of membrane and result in the escape of these enzymes from the cytosol into cellular flow. Alterations in the activity of AST and ALT would affect amino acid metabolism and biochemical regulation in the animals. Haemolysis from tissue damage could result in high levels of free haem causing undesirable toxicity, organ or tissue damage, cellular injury and increased oxidative stress. In a bid to prevent these, damage, free haem is degraded to excretable product such as urea. Low serum protein was observed in the DDS seed residue fed rats compared to control and this could be due to lower protein content of compounded feed, poor feed intake and utilization. Urea was significantly elevated in animals on DDS seed residue-based diet compared to control after 8 weeks continuous feeding. Urea is an antioxidant and high level as observed in DDS seed residue fed rats may be a mechanism for the neutralization of oxidative stress caused by continual intake of formulated seed for eight weeks. This result was further supported by histological assessment (Figures 1, 2 and 3) for liver, kidney and testes respectively. There was tissue damage in the liver, while the kidney and testes report obtained no visible lesions seen, thus showing normal tissue morphology and no damage.

Although the consumption DDS seed residue continual feed for 8 weeks caused increase in body weight which was lower compared to soybean, it might be valuable for weight management. DDS did not cause alterations of the plasma membrane and consequently, leakage of cytosolic enzymatic antioxidants; it however produced oxidative stress, with increase in both enzymatic and non-enzymatic antioxidant. In addition, the
DSS seed residue feeding repeatedly consumed for 8 weeks has the tendency to positively affect the cardiovascular system of the animals with reduced tendency to heart disease as evidenced from serum lipid. There was no significant effect on sperm viability and motility but it produced a significant decrease in sperm count and total abnormal sperm cells which could have implications on reproduction. Thus, DDS seed residue continual consumption for 8 weeks may not be altogether safe as evidenced from liver tissue histopathology report.

\section{Conclusion}

DDS continual ingestion for eight weeks is not safe compared to soybeans in animal feed formulation as evidenced by liver tissue histology, decreased sperm count and oxidative stress.

\section{COMPETING INTERESTS}

The authors declare that they have no competing interests either financially or otherwise.

\section{AUTHORS' CONTRIBUTIONS}

SON and BEO designed the project, SON wrote up the paper while TLA and BEO did the laboratory work.

\section{REFERENCES}

Abolaji AO, Adebayo AH, Odesanmi OS. 2007. Effect of ethanolic extract of Parinari polyandra (Rosaceae) on serum lipid profile and some electrolytes in pregnant rabbits. Res. J. Med. Plants, 1(4): 121-127.

Adikwu MU, Yoshikawa Y, Takada K. 2004. Pharmacodynamic-Pharmacokinetic profiles of metformin hydrochloride from a mucoadhesive formulation of a polysaccharide with antidiabetic property in streptozotocin-induced diabetic rat models. Biomat., 25: 30413048.

Adejuwon SA, Imosemi IO, Ebokaiwe PA, Omirinde JO, Adenipekun AA. 2014. Protective role of Telefairia occidentalis 
in irradiation-induced oxidative stress in rat brain. Int. J. Biol. Chem. Sci., 8(3): 843-853.

Agarwal A, Saleh RA. 2002. Role of oxidants in male fertility: rationale, significance and treatment. Urol. Clin. North Am., 29: 817-827.

Akinbode AA, Alakali J, Adewale PO, Ngadi MO. 2012. Thermophysical properties of Detarium microcarpum seed flower. LWT Food Science and Technology 47: 233-237.

Akpata MI, Miachi OE. 2001. Proximate composition and selected functional properties of Detarium macrocarpum. Plant Foods Human Nutr., 56: 297-302.

Al-Shahib W, Marshall RJ. 2003. The fruit of the date palm: Its possible use as the best food for the future. Int. J. Food Sci. Nutr., 54(4): 247-259.

AOAC (Association of Analytical Chemists). 2005. Official Methods of Analysis of $A O A C$. International. $18^{\text {th }}$ Edition, 2005, Current through revision 2, 2007. Association of Analytical Chemists

Bartels H, Bohmer M, Heierli C. 1972. Serum creatinine determination without protein precipitation. Clinica. Chim. Acta, 37: 193-197.

Claiborne A. 1989. Catalase activity, In Handbook of Methods for Oxygen Radical Research. Greenwald AR (ed). CRC Press: Florida; 234-242.

Diop Ndiaye N, Dhuique-Mayer C, Cisse M, Dornier M. 2011. Fruits rich in vitamins. J Agric Food Chem, 59(22): 12018-12027

Fawcett JK, Scott JF. 1960. A new semimicro method for determination of urea. J. Clin. Pathol., 13:156-159.

Getz GS, Reardon CA. 2006. Diet and murine atherosclerosis. Arterioscler Thromb Vasc. Biol., 26: 242-249.

Glew RS, Dorothy J, Chuang LT, Huang YS, Millson M, Glew RH. 2005. Nutrient content of four edible wild plants from West Africa. Plant Foods Hum. Nutr., 60: 187-193.
Harnafi H, Aziz M, Amrani S. 2009. Sweet Basil (Ocimum basilicum L.) improves lipid metabolism in hypercholesterolemic rats. E-SPEN, the European e-J. Clinical Nutr. Metabolism, 4: e181-e186.

Hartvigsen K, Binde CJ, Hansen LF, Rafia A, Juliano J, Horko S, Steinberg D, Palinsk W, Witztum JL, Li AC. 2007. A dietinduced hypercholesterolemic murine model to study atherogenesis without obesity and metabolic syndrome. Arterioscler Thromb Vasc. Biol., 27: 878-885.

Lacko AG, Barter P, Ehnholm C, van Tol C. 2000. An international symposium on basic aspects of HDL metabolism and disease prevention. J. Lipid Res., 41: 1695-1699.

Lowry OH, Rosenbrough NJ, Farr AI, Randall RJ. 1951. Protein Measurement with Folin- Phenol reagent. J. Biol Chem., 193: $265-75$.

Matos SL, Paula H, Pedrosa ML, Santos RC, Oliveira EL, Chianca Jr DA, Silva ME. 2005. Dietary models for inducing hypercholesterolemia in rats. Brazilian Archives Biol. Technol., 48(2): 203-209.

Misra HP, Fridovich I. 1972. The role of superoxide anion in the autoxidation of epinephrine and a simple assay for superoxide dismutase. J. Biol Chem., 24: 3170-3175.

Nkafamiya II, Manji AJ, Modibbo UU, Umaru HA. 2006. Biochemical evaluation of Cassipourea congoensis (Tunti) and Nuclea latifolia (Luzzi) fruits. African J. of Biotech., 6(19): 2461-2463.

Nwozo SO, Orojobi BF, Adaramoye OA. 2011. Hypolipidemic and antioxidant potentials of Xylopia aethiopica seed extract in hypercholesterolaemic rats. Journal of Medicinal Foods, 14(1/2): 114-119.

Okwu DB. Uchegbu R. 2009. Isolation, characterization and antibacterial activity screening of methoxyamine tetrahydroxyanthocyanidines from Detarium senegalense Gmelin stem bark. Afr. J. Pure Appl. Chem., 3: 001-005. 
Oladiji AT, Jacob TO, Yakubu MT. 2007. Anti-anaemic potentials of aqueous extract of Sorghum bicolor (L.) Moench stem bark in rats. J. Ethnopharmacol., 111: $651-656$.

Oladiji AT, Abodunrin TP, Yakubu MT. 2010. Toxicological evaluation of Tetracarpidium conophorum nut oilbased diet in rat. Food and Chemical Toxicology, 48: 898-902.

Onyechi UA, Ellis PR, Judd PA. 2007. A new polysaccharide, Detarium microcarpum from traditional plant food: its physiological effects on rats. Animal Res. International., 4(1): 601-607.

Owoeye O, Farombi EO (2015) Tomato pomace protects against mercuric chloride- induced neurodegeneration and motor abnormality in adult rat. Int. J. Biol. Chem. Sci., 9(3): 1142-1153.

Rahman MF, Siddiqui MK, Jamil K. 2001. Effects of vepacide (Azadirachta indica) on aspartate and alanine aminotransferase profiles in sub-chronic study with rats. Hum. Exp. Toxicol., 20: 243-249.

Reitman S, Frankel S. 1957. A colorimetric method for the determination of serum glutamicoxalacetic and glutamic pyruvic transaminases. Amer. J. Clin. Pathol., 28: 56-63.

Richmond W. 1973. Preparation and properties of bacterial cholesterol oxidase from Nocardia specie and its application to the enzymatic assay of total cholesterol in serum. Clin. Chem., 19: 1350-1356.

Saramma G, Padmaja C. 2013. Effect of the methanol extract of Ocimum gratissimum on cumen hydroperoxide-induced oxidative stress in rat liver tissue. Int. J. Biol. Chem. Sci., 7(1): 33-46.
Shahjahan M, Sabitha KE, Jamu M, Shyamala-Devi CS. 2004. Effect of Solanum trilobatum agains carbon tetrachloride induced hepatic damage in albino rats. Indian J. Med. Res., 120: 194198.

Sowemimo AA, Pendota C, Okoh B, Omotosho T, Idika N, Adekunle AA, Afolayan AJ. 2011. Chemical composition, antimicrobial activity, proximate analysis and mineral content of seed of Detarium senegalense JF Gmelin. Afr J Biotechn., 10(48): 875-879.

Varshney R, Kale RK. 1990. Effects of Calmodulin antagonists on radiationinduced lipid peroxidation in microsomes. Int J Radiat Biol., 58: 733743.

Vernet P, Aitkenm RJ, Drevet JR. 2004. Antioxidant strategies in the epididymis. Mol Cell Endocrinol., 216(1-2): 31-39.

Visavadiya NP, Narasimacharya AV. 2005. Hypolipidemic and antioxidant activities of Asparagus racemosus in hypercholesterolamic rats. Indian $J$. Pharmacol., 37(6): 376-380.

World Health Organization (WHO). 2003. Organização de Alimentos e Agricultura das Nações Unidas. Manual das necessidades nutricionais humanas. São Paulo: Atheneu, 2003.

WHO (World Health Organization). 2000. Turning the Tide of Malnutrition: Responding to the Challenge of the $21^{\text {st }}$ Century. WHO: Geneva. 